\title{
ABSENCE OF PALMAR DIGITAL TRIRADIUS $d$ IN JAPANESE TWINS AND THEIR FAMILIES
}

\author{
Michio OKaJIMA, ${ }^{1}$ Chizuko IWAYANAGI, ${ }^{2}$ and Eiji INOUYE ${ }^{3 *}$ \\ ${ }^{1}$ Department of Forensic Medicine, Tokyo Medical and Dental University, \\ Tokyo, 113 Japan \\ ${ }^{2}$ Department of Anthropology, the University of Tokyo, \\ Tokyo, 113 Japan \\ ${ }^{3}$ Institute of Brain Research, the University of Tokyo, \\ Tokyo, 113 Japan
}

\begin{abstract}
Summary The absence of palmar digital triradius d was examined in Japanese twins and their parents. The frequency of the absence of triradius $\mathrm{d}$ on the left palm $(0.9 \%)$ was significantly higher than that on the right $(0.1 \%)$, but no sex difference was found. Higher concordance in monozygotic twins $(15 \%)$ than in dizygotic twins $(0 \%)$ and recurrence in families revealed that this trait is genetically determined, although a considerable environmental influence was suggested and the mode of inheritance could not be determined. The manifestation of the absence of triradius $d$ is related to the shifting of main line $D$ towards the ulnar side.
\end{abstract}

\section{INTRODUCTION}

Among the four palmar digital triradii, triradius $\mathrm{c}$ is often abortive or missing. However, the absence of the other triradii, i.e. $a, b$ and $d$, is very rare in normal individuals. There have been reported three pedigrees in which absent triradius d was observed familially (Holt and Sharma, 1977; Abdullah, 1979; Wertelecki et al., 1980). In the other pedigrees reported (Hajn and Pospisil, 1971; David, 1978; Roche et al., 1979), however, the absence of triradius d was found in only one member of each, and the inheritance of this trait was uncertain.

Relatively high frequencies of absent triradius $d$ were reported in the Japanese (Kasai, 1951). Sharma (1979) suggested that the trait appears more frequently among Mongoloids than Caucasoids. For Negroes, Rosa (1979) reported a relatively high frequency in Kenyan samples. Therefore, the absence of the digital triradius $\mathrm{d}$ is of interest in the field of dermatoglyphics.

In this paper, the absence of triradius $d$ was studied genetically among Japanese

Received November 11, 1981

* Present address: Institute for Developmental Research, Aichi Prefectural Colony, Aichi, 480-03 Japan. 
twins and their parents, and, in addition, the relationship of this anomaly to the termination of main line $\mathrm{D}$ was examined.

\section{MATERIALS AND METHODS}

The subjects were 1,010 pairs of normal Japanese twins and both parents of 418 of these pairs. The twin samples consisted of 381 pairs of male and 363 pairs of female monozygotic (MZ) twins, 92 pairs of male and 87 pairs of female likesexed and 87 pairs of unlike-sexed dizygotic (DZ) twins. Therefore, 1,451 males and 1,405 females were examined in total. The twins were those who applied for admission to the Junior High School attached to the Faculty of Education, the University of Tokyo, between 1950 and 1979, and were unselected except for place of residence and school achievements. Palm prints were recorded with black ink on white paper and filed at the Twin Register (Tokyo 12-year-old Twin Register) in the Institute of Brain Research of the same university. The zygosity was determined by serological and anthropological examinations (Inouye, 1956; Inouye, 1962).

\section{RESULTS}

Frequency of absent triradius $d$

On the palm with an absent triradius d, the ridges are arranged in an arciform at the base of digit $\mathrm{V}$ without forming a triradius (Fig. 1a). Occasionally, however, transitional types including those with abortive triradius are found. In this paper, a slight ridge disarrangement as shown in Fig. $1 \mathrm{~b}$ was also classified as an absent triradius $\mathrm{d}$.

The numbers of individuals lacking triradius $d$ on both palms, the right, and the left palm, as well as those with intact triradii $d$, are shown in Table 1 . The absence of triradius d was found on 13 left palms in 1,451 males and on 14 left and
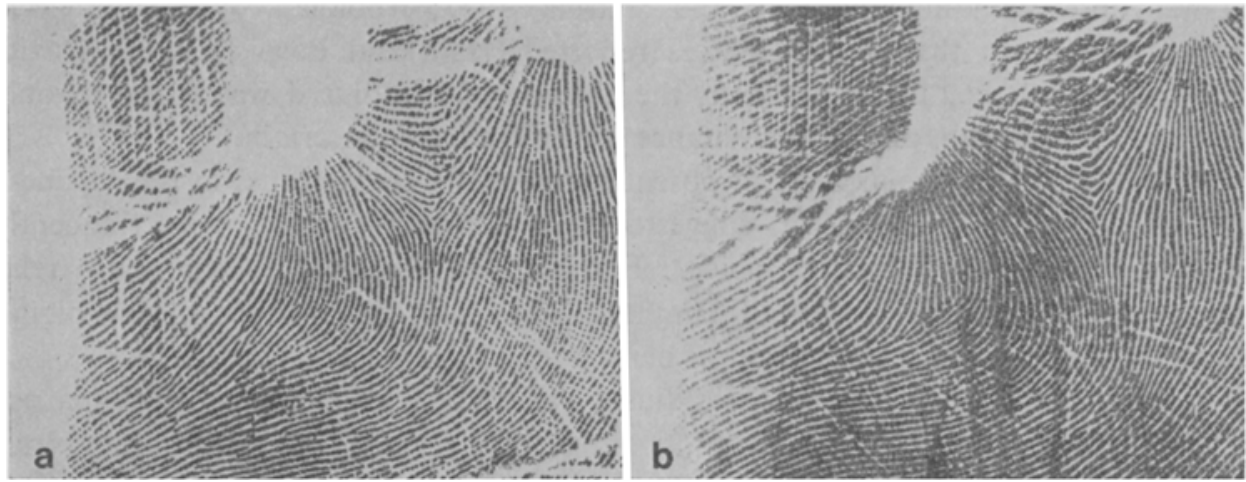

Fig. 1. Absence of palmar digital triradius $d . \quad a$, complete type; $b$, transitional type. Slight ridge disarrangement is present. 
Table 1. Frequency of absent triradius $d$.

\begin{tabular}{|c|c|c|c|c|c|}
\hline & \multirow[b]{2}{*}{ Number } & \multicolumn{4}{|c|}{ Palm } \\
\hline & & $\begin{array}{l}\mathrm{L} R \\
+\quad+\end{array}$ & $\begin{array}{l}\mathrm{L} \mathrm{R} \\
-+\end{array}$ & $\begin{array}{l}\mathrm{L} R \\
+-\end{array}$ & $\underline{L} \mathbf{R}$ \\
\hline Male & 1,451 & 1,438 & 13 & 0 & 0 \\
\hline$\%$ & 100.00 & 99.10 & 0.90 & 0.00 & 0.00 \\
\hline Female & 1,405 & 1,390 & 12 & 1 & 2 \\
\hline$\%$ & 100.00 & 98.93 & 0.85 & 0.08 & 0.14 \\
\hline
\end{tabular}

,+ presence of triradius $d ;-$, absence of triradius $d$.

Table 2. Absent triradius $\mathrm{d}$ in twin pairs.

\begin{tabular}{|c|c|c|c|c|c|c|c|c|c|c|}
\hline & \multirow{3}{*}{$\begin{array}{l}\text { Number } \\
\text { of pairs }\end{array}$} & \multicolumn{9}{|c|}{ Absent triradius $d$ in twin pair } \\
\hline & & \multicolumn{3}{|c|}{ Left } & \multicolumn{3}{|c|}{ Right } & \multicolumn{3}{|c|}{ Left + Right } \\
\hline & & none & one & $\begin{array}{l}\text { both } \\
\text { twins }\end{array}$ & none & one & $\begin{array}{l}\text { both } \\
\text { twins }\end{array}$ & none & one & $\begin{array}{l}\text { both } \\
\text { twins }\end{array}$ \\
\hline MZ twins & 744 & 732 & 10 & 2 & 742 & 2 & 0 & 731 & 11 & 2 \\
\hline \multicolumn{11}{|l|}{$\mathrm{DZ}$ twins } \\
\hline like-sexed & 179 & 177 & 2 & 0 & 179 & 0 & 0 & 177 & 2 & 0 \\
\hline unlike-sexed & 87 & 83 & 4 & 0 & 86 & 1 & 0 & 83 & 4 & 0 \\
\hline
\end{tabular}

3 right palms in 1,405 females. Among these, transitional types were recorded on 3 left palms of the male and 3 left palms of the female subjects. As seen in Table 1 , no sex difference was observed. The combined male-female frequency was 27 $(0.9 \%)$ for the left and $3(0.1 \%)$ for the right palm, and the difference is statistically significant at the $0.1 \%$ level $\left(\chi^{2}=17.72\right.$ after Yates' correction). The absence of triradius $\mathrm{d}$ on one or both palms was found in 28 individuals $(1.0 \%)$, including both twins in $2 \mathrm{MZ}$ pairs and both a parent and a child in $2 \mathrm{DZ}$ twin families.

\section{Comparison of twins}

Absent triradius $d$ was compared between twins for the left and the right palms separately and for both palms together (Table 2). As no sex difference was found, males and females were pooled in this analysis. Among MZ twins, the absence of triradius d was observed in 13 pairs, but was concordant in only 2 of them: in 1 pair on the left palm of both twins and in the other on the left in one twin and on both in the other twin. In the remaining 11 pairs, the absence was discordant and found only in one twin. Among DZ twins, the absence of triradius $d$ was found in 6 pairs, but in only one twin of each pair.

The rate of concordance for the absence in $\mathrm{MZ}$ twins $(2 / 13,15 \%)$ was higher than in $\mathrm{DZ}$ twins $(0 / 6,0 \%)$, though the difference was insignificant $(\mathrm{p}=0.45$ by 
Fisher's direct method). The low concordant rate observed in $\mathrm{MZ}$ twins suggests a strong influence of environmental factors on the manifestation of the trait.

\section{Recurrence in children and parents}

In 418 families, both the parents and their twin offspring were examined (Table 3). Among 411 families in which both parents were unaffected with the absent triradius $d$, this trait was found in a twin in 7 families and in both twins in 1 family. In 7 families in which one parent was affected, the absent triradius $d$ was observed in one of twins in 2 families. In no family were both parents affected. The recurrence ratio in twin individuals obtained from 7 families with one affected parent is $2 / 14(14.3 \%)$, and that from 411 families with unaffected parents is $9 / 822(1.1 \%)$. The difference between these two values is significant $\left(\chi^{2}=9.68\right.$ after Yates' correction, $\mathrm{p}<0.01$ ). Similarly, the recurrence ratio in parents obtained from 10 families with one or two affected twins, $2 / 20(10.0 \%)$, and that from 408 families with unaffected twins, $5 / 816(0.6 \%)$, presented a significant difference $(p=0.01$ by Fisher's direct method). As the recurrence ratio in the families having an affected person is higher than in those without affected ones, it is suggested that the absent triradius $\mathrm{d}$ is, to some extent, determined genetically.

\section{Association of absent triradius $d$ with the termination of main line $D$}

Of 28 individuals with absent triradius $d$, the trait was expressed unilaterally in 26 , i.e. 25 on the left and 1 on the right palm. For the 25 individuals lacking triradius $d$ on the left palm only, the termination of main line $D$ was examined on the opposite palm (Table 4). As no sex difference was found in the frequencies

Table 3. Number of families according to the mating type of parents and the number of twins affected with absent triradius $d$ in the family.

\begin{tabular}{|c|c|c|c|c|c|}
\hline \multirow{2}{*}{\multicolumn{2}{|c|}{ Mating type }} & \multicolumn{3}{|c|}{ No. of affected twins } & \multirow{2}{*}{ Total } \\
\hline & & none & one & both twins & \\
\hline \multicolumn{6}{|c|}{ Unaffected $\times$ Unaffected } \\
\hline $\mathrm{MZ}$ twins & & 312 & 5 & 1 & 318 \\
\hline \multirow[t]{2}{*}{$\mathrm{D} Z$ twins } & like-sexed & 65 & 0 & 0 & 65 \\
\hline & unlike-sexed & 26 & 2 & 0 & 28 \\
\hline Total & & 403 & 7 & 1 & 411 \\
\hline \multicolumn{6}{|c|}{ Affected $\times$ Unaffected } \\
\hline MZ twins & & 4 & 0 & 0 & 4 \\
\hline \multirow[t]{2}{*}{$\mathrm{DZ}$ twins } & like-sexed & 0 & 1 & 0 & 1 \\
\hline & unlike-sexed & 1 & 1 & 0 & 2 \\
\hline Total & & 5 & 2 & 0 & 7 \\
\hline Affected $\times$ Affe & & 0 & 0 & 0 & 0 \\
\hline
\end{tabular}


Table 4. Relation between terminals of main line $D$ and absence of triradius d: Frequencies of exits of main line D on the palms of opposite side and of relatives of an individual with absent triradius $d$.

\begin{tabular}{|c|c|c|c|c|c|c|c|c|}
\hline & \multirow{2}{*}{$\begin{array}{l}\text { Number } \\
\text { of palms }\end{array}$} & \multicolumn{7}{|c|}{$\begin{array}{l}\text { Exit of main line } D \\
\text { Left palm }\end{array}$} \\
\hline & & $\underset{\mathrm{d}}{\operatorname{absent}}$ & $\mathrm{X}$ & 7 & 8 & 9 & 10 & 11 \\
\hline Palm of opposite side* & 25 & & & & & & & \\
\hline$\%$ & 100.0 & & & & & & & \\
\hline \multicolumn{9}{|l|}{ Palms of relatives } \\
\hline Co-twin in $\mathrm{MZ}$ pairs* & 10 & 0 & 0 & 8 & 0 & 2 & 0 & 0 \\
\hline$\%$ & 100.0 & 0.0 & 0.0 & 80.0 & 0.0 & 20.0 & 0.0 & 0.0 \\
\hline Co-twin in DZ pairs* & 5 & 0 & 0 & 5 & 0 & 0 & 0 & 0 \\
\hline$\%$ & 100.0 & 0.0 & 0.0 & 100.0 & 0.0 & 0.0 & 0.0 & 0.0 \\
\hline Parents & 16 & 0 & 0 & 8 & 1 & 5 & 0 & 2 \\
\hline$\%$ & 100.0 & 0.0 & 0.0 & 50.0 & 6.3 & 31.2 & 0.0 & 12.5 \\
\hline Children & 10 & 0 & 0 & 3 & 0 & 4 & 1 & 2 \\
\hline$\%$ & 100.0 & 0.0 & 0.0 & 30.0 & 0.0 & 40.0 & 10.0 & 20.0 \\
\hline \multicolumn{9}{|l|}{ Control } \\
\hline $\begin{array}{l}\text { Combined subjects } \\
\text { of this study }\end{array}$ & 2,856 & 27 & 33 & 1,214 & 45 & 993 & 67 & 477 \\
\hline$\%$ & 100.0 & 0.9 & 1.2 & 42.5 & 1.6 & 34.8 & 2.3 & 16.7 \\
\hline & \multirow{2}{*}{\multicolumn{8}{|c|}{$\begin{array}{c}\text { Exit of main line D } \\
\text { Right palm }\end{array}$}} \\
\hline & & & & & & & & \\
\hline & & $\begin{array}{l}\text { absent } \\
\mathrm{d}\end{array}$ & $X$ & 7 & 8 & 9 & 10 & 11 \\
\hline Palm of opposite side* & 25 & 0 & 1 & 17 & 1 & 5 & 0 & 1 \\
\hline$\%$ & 100 & 0.0 & 4.0 & 68.0 & 4.0 & 20.0 & 0.0 & 4. 0 \\
\hline \multicolumn{9}{|l|}{ Palms of relatives } \\
\hline Co-twin in $\mathrm{MZ}$ pairs* & 10 & 0 & 0 & 5 & 1 & 3 & 0 & 1 \\
\hline$\%$ & 100.0 & 0.0 & 0.0 & 50.0 & 10.0 & 30.0 & 0.0 & 10.0 \\
\hline Co-twin in DZ pairs* & 5 & 0 & 0 & 2 & 0 & 2 & 0 & 1 \\
\hline$\%$ & 100.0 & 0.0 & 0.0 & 40.0 & 0.0 & 40.0 & 0.0 & 20.0 \\
\hline Parents & 16 & 0 & 0 & 6 & 1 & 7 & 1 & 1 \\
\hline$\%$ & 100.0 & 0.0 & 0.0 & 37.5 & 6.3 & 43.6 & 6.3 & 6.3 \\
\hline Children & 10 & 0 & 0 & 3 & 1 & 3 & 0 & 3 \\
\hline$\%$ & 100.0 & 0.0 & 0.0 & 30.0 & 10.0 & 30.0 & 0.0 & 30.0 \\
\hline \multicolumn{9}{|l|}{ Control } \\
\hline $\begin{array}{l}\text { Combined subjects } \\
\text { of this study }\end{array}$ & 2,856 & 3 & 6 & 748 & 100 & 981 & 51 & 967 \\
\hline$\%$ & 100.0 & 0.1 & 0.2 & 26.2 & 3.5 & 34.3 & 1.8 & 33.9 \\
\hline
\end{tabular}

* Cases in which absent triradius $d$ is observed on the right palm of the affected individual are excluded.

Vol. 27, No. 1, 1982 
of D-line exits, male and female data were pooled. On 17 out of 25 right palms $(68 \%)$, main line D ended in the interdigital area IV (position 7 ), and the frequency was significantly higher than in the combined subjects of this study, $26.2 \%\left(\chi^{2}=\right.$ $22.21, \mathrm{p}<0.001$ ). On the contrary, the frequency of main line $\mathrm{D}$ ending in the interdigital area II (position 11) was $1(4 \%)$, which was significantly lower than in the combined subjects, $33.9 \%\left(\chi^{2}=8.61\right.$ after Yates' correction, $\left.\mathrm{p}<0.01\right)$.

The terminals of main line $D$ were examined on both palms of the non-affected twin for the $10 \mathrm{MZ}$ and $5 \mathrm{DZ}$ twin pairs in which the trait was expressed on only the left palm of one of twins (Table 4). On the left palm, homologous to the affected palm of the index twin, main line D ended in the interdigital area IV on 8 out of 10 palms $(80 \%)$ for $\mathrm{MZ}$ and on all of $5(100 \%)$ for $\mathrm{DZ}$ twins. On the right palm, heterologous to the affected palm, the frequency was $5(50 \%)$ for $\mathrm{MZ}$ and $2(40 \%)$ for $\mathrm{DZ}$ twins. These values are higher than those of the combined subjects of this study, i.e. $42.5 \%$ on the left and $26.2 \%$ on the right palm. The frequency of main line $\mathrm{D}$ ending in the interdigital area II was zero for both $\mathrm{MZ}$ and DZ twins on the homologous palm, and 1 for each $(10 \%$ and $20 \%$, respectively) on the heterologous palm. These frequencies are less than those observed in the combined subjects of this study, i.e. $16.7 \%$ on the left and $33.9 \%$ on the right palm.

Thus, when triradius $d$ is absent, the termination of main line $D$ tends to shift towards the uInar side, i.e. from the II to IV interdigital area on the opposite palm of the same individual as well as on the homologous and heterologous palms of the co-twin.

The D-line terminals were also examined in 8 pairs of parents and 5 pairs of twins whose child or parent lacked triradius $d$. The frequencies did not differ from the combined subjects (Table 4), and the shift of main line D described above was not observed, probably because of the small sample size.

\section{DISCUSSION}

Holt and Sharma (1977) reported two Indian sisters with the absence of triradius $d$ and suggested the possibility of inheritance by a rare recessive gene. Presenting a large Iraqui family in which a father and his daughter possessed the absence of triradius d, Abdullah (1979) suggested that the simple Mendelian dominant inheritance is unlikely. Recently, Wertelecki et al. (1980) reported a sibship of American blacks in which 2 brothers of 5 sibs had the trait, and gave support to the suggestions that this trait is genetically determined. However, other family studies have failed to reveal the recurrence of absent triradius $d$, though the relatives of the probands were examined, i.e. the parents and grandparents of a female proband (Hajn and Pospisil, 1971); 10 relatives, including a MZ twin brother, of 4 probands (David, 1978), and three generations of relatives of a female proband (Roche et al., 1979). Thus, the genetic basis of this rare condition remains uncertain. 
In the present study, the absence of triradius $d$ was found in both a parent and a child in 2 out of 418 families, and the recurrence ratios both in children and in parents of affected individuals are higher than in those of unaffected, indicating that the occurrence of this condition is genetically determined. However, the ratios are not high enough to support the mode of dominant inheritance with high penetrance. Nor was inheritance by a recessive gene confirmed, since the condition was not recognized in the co-twin of the probands in $6 \mathrm{DZ}$ pairs. On the other hand, strong environmental effects are suggested, because the concordance rate in $M Z$ twins (2 out of 13) showed a highly reduced penetrance. Though a possibility of dominant inheritance with a highly reduced penetrance is not to be excluded, the mode of inheritance cannot be determined from the present observations.

On the other hand, the association of the absent triradius $d$ with the termination of main line $D$ was suggested. When triradius $d$ is absent, the ending of main line $\mathrm{D}$ in the interdigital area IV increases on the opposite palm of the same individual and on the homologous and heterologous palms of the co-twin, and both of these characteristics appear more frequently on the left palm than on the right. From these results, it appears likely that these two characteristics are related in their manifestation by some common factors involving genetic backgrounds.

The frequency of absent triradius $\mathrm{d}$ in the Japanese was $0.9 \%$ on the left and $0.1 \%$ on the right palm in this study, and $0.6 \%$ and $0.2 \%$, respectively, in the study on 2,500 subjects by Kasai (1951). In Caucasoids, the frequency was zero on the left and $0.2 \%$ on the right palm in 1,281 Germans (Cummins and Midlo, 1961), and $0.2 \%$ and $0.1 \%$ in 4,360 British subjects (Dennis and Sunderland, 1979). From these data obtained from large samples, this trait is believed to be more common among Mongoloids than among Caucasoids, as Sharma (1979) assumed. Besides, there are some cases reported in other Asian populations, including 3 Korean subjects (Keith, 1924) and 1 Philippine Igorot (Wilder, 1930). The racial difference in the frequency of this trait can be associated with that of D-line exits, i.e. the D-line ending in the interdigital area IV appears more frequently in Mongoloids than in Caucasoids. This may be an indication of the racial difference in the liability for the occurrence of absent triradius d.

This research was partly supported by the Grant-in-Aid for Scientific Research No. 357194 of the Ministry of Education, Science and Culture of Japan.

\section{REFERENCES}

Abdullah, N.F. 1979. Inheritance of palmar triradii suppression. Birth Defects: Original Article Series. Vol. 15, No. 6: 529-538.

Cummins, H., and Midlo, C. 1961. Finger Prints, Palms and Soles. Dover Publications, New York.

Dennis, R.L.H., and Sunderland, E. 1979. Dermatoglyphic variation in the human populations of the North Pennine Dales, North England. Am. J. Phys. Anthrop. 50: 309-324. 
David, T.J. 1978. Absence of the d triradius. Ann. Hum. Genet, Lond. 42: 193-196.

Hajn, V., and Pospisil, M.F. 1971. Heredity of some non common dermatoglyphic patterns on the human palm. Acta Facultatis Rerum Naturalium Universitatis Comenianae (Anthropologia) 16: 71-90.

Holt, S.B., and Sharma, P.D. 1977. Absence of triradius d on the palms of normal people. Ann. Hum. Genet., Lond. 41: 195-197.

Inouye, E. 1956. A review on the zygosity diagnosis of twins. Jpn. J. Human Genet. 1: 24-31. Inouye, E. 1962. Zygosity diagnosis of twins of the Japanese by Essen-Möller's formula. In Studies on Twins. III. Nihon-Gakujutsu-Shinkokai, Tokyo, pp. 1-13 (in Japanese).

Kasai, K. 1951. Report on the investigation of palmar patterns in 2500 Japanese. Jpn. J. Legal Med. 5: 140-146 (in Japanese).

Keith, H.H. 1924. Racial differences in the papillary lines of the palm. Am. J. Phys. Anthrop. 7: 165-206.

Roche, E.M., Roche, A.F., and Siervogel, R.M. 1979. Absence of triradius d in a three-generation pedigree and other variations of main line D. Am. J. Phys. Anthrop. 51: 389-392.

Rosa, P.J. 1979. Absence of palmar triradius d in a series of Kenyan samples. Ann. Hum. Biol. 6: 269-278.

Sharma, P.D. 1979. Further observations on absence of palmar triradius d in normal people. Am. J. Phys. Anthrop. 50: 213-214.

Wertelecki, W., Plato, C., and Plato, C.C. 1980. Absent d triradius and dotting of the ridges in siblings. Hum. Hered. 30: 368-371.

Wilder, I.W. 1930. The morphology of the palmar digital triradii and main lines. J. Morph. 49: 153-221. 